\title{
A REVIEW ON THE RECENT TRENDS IN FINANCIAL INCLUSION: THE RESEARCH JOURNEY SO FAR

\author{
Binoy Thomas ${ }^{1}$, P. Subhashree ${ }^{2 *}$
}

${ }^{1}$ Ph.D Scholar, Business School, Vellore Institute of Technology, Vellore, India; ${ }^{2 *}$ Professor \& Dean, Business School, Vellore Institute of Technology, Vellore, India.

Email: ${ }^{1}$ binoythomas.n@gmail.com, ${ }^{2 *}$ suba.n.raja@gmail.com

Article History: Received on $29^{\text {th }}$ February 2020, Revised on $24^{\text {th }}$ May 2020, Published on $14^{\text {th }}$ July 2020

\begin{abstract}
Purpose of the study: This paper tries to review the existing literature on financial inclusion and to discuss the various definitions of financial inclusion, its diverse dimensions comprehensively - demand side and supply side - and multiple explanatory variables (economic, demographic, behavioural, and social factors) to explain the level of financial inclusion.
\end{abstract}

Methodology: From various databases and e-journals, the papers were retrieved on the topic of financial inclusion during the time span of the last 15 years (2005-2019). After reading the abstract of totally collected 140 research papers, the researchers have chosen 84 articles for the present study based on the relevance of the content to the topic under study. The collected information was classified as per the major themes.

Main Findings: Much research has been conducted on the measurement and impact assessment of financial inclusion, But the studies on the explanatory variables are comparatively fewer. Among the various factors influencing the financial inclusion level, no much emphasis has been laid on the usage dimension; the key role of behavioural, psychological, and sociological factors on the financial inclusion level still remains unexplored.

Applications of this study: This paper will be useful for theoretical researchers who prefer to explore the factors that influence the usage dimension of financial inclusion. The policymakers and practitioners in the area of financial inclusion will be able to improve the effectiveness of their policies and implementation strategies of financial inclusion.

Novelty/Originality of this study: This review paper explores the juncture at which the current research on financial inclusion has arrived. It would serve as a starting point for further in-depth explorations in the various segments of financial inclusion. Also, the present study points out and suggest potential areas for further research in the field of financial inclusion.

Keywords: Financial Inclusion, Recent Trends in Financial Inclusion, Financial Inclusion Index, Inclusive Finance, Financial Exclusion, Determinants of Financial Inclusion.

\section{INTRODUCTION}

Financial inclusion, as an effective strategy for poverty alleviation and sustainable economic growth, has been emerged as a hot topic for discussion today all over the world.It has captured keen attention among international and national organizations, financial institutions, and policymakers. World Bank has recognized financial inclusion as an effective tool for poverty mitigation and target financial access to all segments of the population. Through Maya Declaration and Global Partnership for Financial Inclusion, G20 economies acknowledge financial inclusion as one of the key pillars of poverty alleviation and economic development and commit themselves for promoting financial inclusion (Cihak et al., 2016). At least for the last two decades, World Bank has widely invested in developmental economics research emphasizing the financial inclusion for poverty reduction and for promoting economic welfare, especially in developing economies. Still, 44\% among lower \& middle-income households remain unbanked (Mundial, 2014); low-income households still live and work in the informal economy (Cull et al., 2014).

During the past two decades, there is a boundless technological advancement in banking channels such as online fund transfer, e-payments, internet banking, card payments; but most of these benefits are reduced to the minuscule highincome group or upper-middle-income groups of the society. Even the most basic financial services are still beyond the reach of the lower-income group. The economic disparity among the rich and the poor segments propel a wide range of health and social problems and undermine the sustainability of economic growth. The inclusive economy is a prerequisite for the effective implementation of social welfare and development schemes (Cull et al., 2014; Sachindra, 2013). The inclusive economy creates a better harmonious society with equitable distribution of income and resources. Financial inclusion has proved to be an effective solution for attaining the inclusive economic growth (Chibba, 2009; Dixit \&Ghosh, 2013; Cull et al., 2014; Shah \&Dubhashi, 2015). Using empirical evidence, Demirguc-Kunt et al. (2017) have stated how the use of financial services can contribute to inclusive growth and economic development.

The research on developmental economics in the past several decades has laid the predominant emphasis on assessing the impact of microcredit services in reducing the poverty level. But the current focus of the research is on the platform that the usage of formal bank accounts and digital payments has greater on poverty alleviation and economic welfare than the microcredit services do. Beck (2016) and Demirguc-Kunt et al. (2017) pointed out that the focus of the research has been recently shifted more towards the ownership and usage of bank accounts and other financial services. Even 
after the dedicated efforts to irradiate poverty by using microcredit services for long years, the majority of the poor in the world still live in the informal economy; the operations of the small businesses and micro-entrepreneurs are in shadow economy (Cull et al. 2014). In this context, various international and national economic databases such as Global Findex 2017 and PradhanMantri Jan Dhan Yojana (PMJDY) have rightly commented that the inactive bank accounts and the infrequent use of active bank accounts are the major challenges of today in the formalization of Indian economy. As this all previous research calls for the need for research in the financial inclusion area, this present study aims to comprehensively map the current research trends in the area of financial inclusion.

In this review paper, we discuss the various dimensions (both demand side and supply side) and explanatory variables used by previous researchers in measuring and explaining the financial inclusion level. This paper starts with (1) introduction, followed by (2) research methodology, and then (3) followed by a discussion on various definitions put forth by various authors. It is followed by explaining (4) the impact and benefits of financial inclusion endeavours at various levels - micro level and macro level. Then, (5) various dimensions (both demand side and supply side) of financial inclusion used by various studies are enumerated and explained in detail. After a discussion on (6) explanatory variables that determine the trend of financial inclusion, the section on (7) the results and the discussion based on it is followed. Finally, this paper is concluded by stating (8) the limitations of the present study and pointing out the scope for further research.

\section{METHODOLOGY}

For reviewing the literature on financial inclusion, various databases and e-journals were used. The keywords used for retrieving the papers were 'Financial inclusion' OR 'Financial exclusion' (as an opposite term for financial inclusion) OR 'inclusive finance'. The databases, search engines, and e-journals used are Ebscohost, elibrary, worldbank, Emarald, Google Scholar, JSTOR Journals, Proquest, SAGE Journals, Science Direct (Elsevier), Scopus, Taylor \& Francis, Wiley Online Library. The papers in the time span of the last 15 years (2005-2019) were chosen for the present study. The year 2005 was chosen as the starting point following the milestone event in the history of financial inclusion, i.e. the exhortation of United Nations former Secretary-General Kofi Annan towards its participant economies to concentrate on the issues related to financial inclusion. Only the articles published in the English language has considered for this study. In the search, totally 140 articles were gathered (Table 1); they are distributed as Ebscohost (7), elibrary, worldbank (10), Emarald (9); Google Scholar (28); JSTOR Journals (11); Proquest (3); SAGE Journals (19); Science Direct (16); Scopus (12); Taylor \& Francis (14); Wiley Online Library (11).

Table 1: Database / E-Journals and Year of Publication of Papers

\begin{tabular}{|c|c|c|c|c|c|c|c|c|c|c|c|c|c|c|c|}
\hline $\begin{array}{c}\text { Database / E- } \\
\text { Journals [2005-19] }\end{array}$ & '05 & $\begin{array}{l}\text { '0 } \\
6 \\
\end{array}$ & $\begin{array}{l}\text { '0 } \\
7\end{array}$ & $\begin{array}{l}0 \\
8 \\
\end{array}$ & $\begin{array}{l}9 \\
9 \\
\end{array}$ & $\begin{array}{l}\text { '1 } \\
\mathbf{0}\end{array}$ & $\begin{array}{l}\text { '1 } \\
1 \\
\end{array}$ & $\begin{array}{l}\text { '1 } \\
2\end{array}$ & $\begin{array}{l}\text { '1 } \\
3 \\
\end{array}$ & $\begin{array}{l}\text { '1 } \\
4 \\
\end{array}$ & $\begin{array}{l}\text { '1 } \\
5 \\
\end{array}$ & $\begin{array}{l}91 \\
6 \\
\end{array}$ & $\begin{array}{l}\text { '1 } \\
7 \\
\end{array}$ & $\begin{array}{l}91 \\
8 \\
\end{array}$ & $\begin{array}{l}\text { '1 } \\
9 \\
\end{array}$ \\
\hline Ebscohost & & & & 1 & & & & 1 & & & 2 & & & 2 & 1 \\
\hline elibrary.worldbank & 2 & & & & & 1 & 1 & 1 & & & 1 & 1 & 1 & 1 & 1 \\
\hline \multicolumn{16}{|l|}{ Elsevier } \\
\hline Emarald & & & & & & & 1 & & 1 & & 1 & 1 & 2 & 1 & 2 \\
\hline Google Scholar & 1 & 1 & 1 & & & 2 & 2 & 3 & 3 & 4 & 3 & 3 & 2 & 2 & 1 \\
\hline JSTOR Journals & & 2 & 1 & & & & 1 & 1 & 1 & 1 & 1 & & 2 & 1 & \\
\hline Proquest & & & & & & & 1 & & & & 1 & & & & 1 \\
\hline SAGE Journals & & & & 1 & 1 & 1 & 2 & 1 & 2 & 2 & 2 & 4 & & 1 & 2 \\
\hline Science Direct & 1 & & & & & 2 & & 2 & & 4 & & 3 & 1 & 3 & \\
\hline Scopus & 1 & & & & 1 & 1 & & 3 & & 1 & & 3 & & 1 & 1 \\
\hline Taylor \& Francis & 1 & & & & 2 & & & 2 & 1 & & & 3 & 2 & 2 & 1 \\
\hline Wiley Online Library & & & 1 & & 1 & & 2 & 1 & 1 & 2 & 1 & & & 2 & \\
\hline TOTAL [140] & 6 & 3 & 3 & 2 & 5 & 7 & 10 & 15 & 9 & 14 & 12 & 18 & 10 & 16 & 10 \\
\hline
\end{tabular}

The abstract of these 140 research papers was read by the authors. Based on the direct relevance of the content to the topic of study, 84 papers were selected for full text detailed reading and reviewing. The information collected from the papers was classified as per the major themes such as definition, the impact of financial inclusion - macro level and micro level, measurement models, and explanatory variables.

\section{DEFINITIONS OF FINANCIAL INCLUSION}

Financial inclusion is the process of ensuring access to financial services, including credit services to low-income groups at an affordable cost (Rangarajan, 2008). Kim (2016) refers to financial inclusion to the accessibility of all adults into the transaction accounts, savings, affordable loans, life insurance and general insurance products provided by the formal 
financial institutions. By the financial services, it includes remittance services, transaction account, credit services, savings, life insurance, general insurance, etc. (Demirguc-Kunt \& Klapper, 2012). Ambarkhane et al. (2016)also include the other non-banking financial services such as a pension, social welfare schemes, insurance, and financial literacy into the wide scope of financial inclusion. Beck (2016) extends the accessibility of financial services also to the enterprises.

Financial inclusion is viewed not only as a 'state of being' financially included but also as a 'process of becoming' (Sarma, 2008; Sarma\&Pais, 2011). The mission of financial inclusion never ends up providing' mere access' into the financial services (Beck et al., 2007; Allen et al., 2012); rather it extends towards its 'continuous usage'. Some authors have stressed more on the usage dimension rather than the access to financial services (Demirguc-Kunt \& Klapper, 2012). Because mere access alone into the basic financial services need not necessarily lead the individuals and microsmall enterprises into the full benefit out of the formal financial services (Cihak et al., 2016).

\section{IMPACT OF FINANCIAL INCLUSION}

Beck (2016) observed that financial inclusion is never considered as an end in itself; rather, it aims to help to improve the individual and aggregate welfare. The financial inclusion increases the well-being and dignity of the target group who live in poverty and remote areas, who never had access to financial services provided by formal financial institutions. According to Anand\&Chhikara (2013), when financial inclusion increases by one percentage, the Human Development Index increases by $0.142 \%$ on an average across the world. Researchers have identified manifold benefits of financial inclusion at the macro level and at the micro-level.

Impact at Micro Economic Level: Financial inclusion can positively impact the individual household and local economy, especially to the Bottom of the Pyramid (Allen et al., 2012). The poor get access to banking and other financial services such as saving accounts, payment services, credit, insurance, etc. A bank account is a catalyst acting as the entry point into the whole spectrum of financial services (Demirguc-Kunt et al., 2017). The entry into saving accounts would significantly increase the savings level (Aportela, 1999) and inculcate a strong saving habit among the unbanked. The low-income households can better manage the economic shocks when they get a safer place to save and when the credit facilities readily available (Demirguc-Kunt et al., 2017).

The low-income households would be able to invest more in the education and health care of the family members. With inclusive financial systems, the economic well-being and social esteem of the poor will be improved (Bauchet et al., 2011); the female members will be more empowered (Ashraf et al., 2010). The financial inclusion will assist the lowincome households in starting microenterprises or in expanding the existing income-generating programs (Cull et al., 2014; Dupas et al., 2012; Mundial, 2014). If the micro-small enterprises continue to function in the informal economy, they may be compelled either to curtail their future growth prospects or to depend on limited private sources such as money lenders, friends, personal funds, and family (Farazi, 2014).

When the payments of government subsidies and social security schemes are shifted from cash transactions into account transactions, the time spent and cost involved for travelling and waiting in the queues will be significantly reduced (Aker et al., 2013). The proper coordination among all stakeholders of financial inclusion will help all the MGNREGA beneficiaries to receive their wages in their personal savings accounts linked to the formal financial institutions (Jain \& Jain, 2013). The day-to-day financial transactions (utility bills payments, school fees payments, etc.) can be made more safely and efficiently (Demirguc-Kunt et al., 2017). The identity proof and the biometric-linked bank accounts will empower them to facilitate property ownership, to undertake entrepreneurial endeavours, to give access to insurance, and other financial services (Swamy, 2011).

Benefits at Macro Economic Level: The financial inclusion also impacts the macroeconomic levels (Cull et al., 2014). Causal relationships are found to exist between the financial inclusion level and the economic growth level (Cull et al., 2014), financial inclusion and financial stability (Hannig\& Jansen, 2010; Aduda\&Kalunda, 2012), etc. The savings and deposits accumulated into the formal system will expand the formal financial sector (Busch, 2017). In its turn, it would boost the stability in the formal financial sector (Busch, 2017; Morgan \&Pontines, 2014; Aduda\&Kalunda, 2012). Financial inclusion would accelerate inclusive economic growth (Mundial, 2014; Karpowicz, 2014; Dixit \&Ghosh, 2013; Demirguc-Kunt et al., 2017), mitigate poverty (Mundial, 2014) and income inequality (Kim, 2016). Researchers have found a significant correlation between financial inclusion, human development and the income level of the countries (Nanda \&Kaur, 2016; Sarma\&Pai, 2011; Sarma, 2016). In the developing countries, the lack of sufficient access into the financial services for the low-income group has been identified as a crucial threat to the future economic growth (Sachindra, 2013; Swamy, 2011).

The accessibility into the formal credit services will result in the expansion of micro-enterprises and in the launch of new entrepreneurship endeavours (Mohan, 2006). Consequently, the economy will grow at a faster rate, increase the GDP level, and create new employment opportunities. The availability of adequate credit from formal financial institutions will generate entrepreneurial spirit among the low-income households (Kaur\& Singh, 2015) and enable them to start new microenterprises or to expand the existing income-generating programs (Dupas et al., 2012; Cull et al., 2014; Mundial, 2014). 
Through the mechanism of direct benefit transfer, the government can distribute subsidies, wages, social security funds, welfare funds, pension, etc. directly into the bank accounts of the beneficiary; it would considerably cut down the administrative expenses of government (Mundial, 2014). Moreover, the funds would reach the intended recipients; the leakages will be plugged in, and reduce the subsidy bills of government providing them only to the real deserving beneficiaries (Kaur\& Singh, 2015). In addition, the direct benefit transfer would enhance the security of payments and lower the associated crime incidents (Mundial, 2014). Shehu (2012) have observed that the promotion of financial inclusion would be an effective strategy against anti-money laundering and counter financing of terrorism.

\section{MEASUREMENT OF FINANCIAL INCLUSION}

During the last two decades, several researchers and international organizations have attempted to formulate a comprehensive model for measuring the level of financial inclusion. A multidimensional approach has been widely adopted to capture the different facets of financial Inclusion (Sarma, 2010; Cnaan et al., 2012; Gupte et al., 2012; Sarma, 2016). Table 2 shows the different variables used by previous researchers for calculating the Financial Inclusion Index or Index of Financial Inclusion.

Table 2: Dimensions used for Measuring Financial Inclusion Index

\begin{tabular}{lll}
\hline No & Constructs & References \\
\hline 1 & Accessibility & $\underline{\text { Arora (2010); Gupte et al. (2012); Nandru et al.(2015); Rahman (2013); Sethy }}$ \\
\hline 2 & Outreach & $\underline{\text { (2016); Tripathi et al. (2016); Yorulmaz (2013) }}$ \\
\hline $\begin{array}{lll}\text { Ambarkhane et al. (2016); Arora (2010); CRISIL (2015); Gupte et al. (2012); } \\
\text { Sarma (2010); Sethy (2016); Tripathi et al. (2016) }\end{array}$ \\
\hline 3 & Usage & $\underline{\text { Ambarkhaneet al. (2016); Gupte et al. (2012); Kulkarni\&Warke (2015); }}$ \\
\hline 4 & Credit Penetration & $\underline{\text { CRISIL (2015); Demirguc-Kunt \& Klapper (2012); Tripathi et al. (2016) }}$ \\
\hline 5 & Deposit Penetration & $\underline{\text { Cnaan et al. (2012); CRISIL (2015); Honohan (2005); Demirguc-Kunt \& }}$ \\
\hline 6 & Availability & $\underline{\text { Klapper (2012); Tripathi et al. (2016); Mylenko (2009) }}$ \\
\hline 7 & Cost & Arora (2010); Gupte et al. (2012); Kulkarni\&Warke (2015) \\
\hline 8 & Financial Literacy & $\underline{\text { Kulkarni\&Warke (2015); Tripathi et al. (2016) }}$ \\
\hline
\end{tabular}

Source: Compiled by authors

Honohan (2005) adopts two general dimensions in the financial inclusion measurement model: demand side and supply side. Some researchers have widely used three-fold dimensions of (1) Access/availability - supply side; (2) Usage demand side (Beck et al., 2007). Many others have used three dimensions in the measurement model: (1) Penetration; (2) Access or Availability; (3) Usage (Bihari, 2011; Ghosh, 2012; Kumar, 2013; Mukhopadhyay, 2016; Sarma, 2010). While Penetration and Access are the supply side dimensions of financial inclusion, usage represents its demand-side dimension. Each dimension is measured using proxy indicators: Penetration is measured based on the number of bank accounts; Access or Availability through the aggregate number of branches of all banks and their ATM counters; Usage through the credit and deposit volumes to the GDP of the respective country (Beck et al., 2007; Honohan, 2005; Kendall et al., 2010; Yorulmaz, 2013; Kim, 2016; Ambarkhane et al., 2016; Sethy, 2016).

In addition to the supply side (penetration, access) and demand-side (Usage) dimensions, some studies have proposed additional variables into the measurement model: educational attainment, literacy (Ambarkhane et al., 2016); infrastructure availability, institutional quality (Ghosh, 2012), branch penetration, deposit penetration, credit penetration (CRISIL, 2015), geographic branch penetration, demographic branch penetration, and demographic ATM penetration (Sethy, 2016), infrastructure development, drag factors (Ambarkhane et al., 2016), ease of transaction, cost of the transaction, outreach (Gupte et al., 2012; Arora, 2010); take-up rate, level of satisfaction (Rahman, 2013), etc.

The measurement models for financial inclusion include not only the data of banking services, but also the data from micro-financial institutions (Honohan, 2005; CRISIL, 2015), non-banking financial companies, and insurance companies (Ambarkhane et al., 2016) in its fold. Some researchers have added the 'barriers' dimension to the financial inclusion measurement model as one of its determinants (Camara\&Tuesta, 2014). The common barriers such as high transaction cost, geographical distance with banks, lack of accessibility, and lack of proper documentation, and excessive documentation works are identified (Demirguc-Kunt \& Klapper, 2012; Mundial, 2014).

By analyzing the current scenario of financial inclusion in India, CRISIL has proposed a comprehensive financial inclusion index (CRISIL Inclusix). It is based on three tangible and critical dimensions: branch penetration, credit penetration, and deposit penetration. Branch penetration refers to the number of branches of formal financial institutions in a district for one lakh people. It assesses the ease of accessibility into the formal financial services for the people residing in a specific geographical area. Credit penetration refers to the number of loan accounts, the number of small borrower loan accounts, and to the number of agricultural advances in a specific district for one lakh people. It denotes the accessibility of loans and advances distributed in a specific district, the Access of credit for small borrowers who 
typically face financial non-inclusion, and the Access of farmers to credit. Deposit penetration refers to the number of saving accounts in the formal financial institution in a district for one lakh people. It calculates the number of saving accounts issued by formal financial institutions in a district. CRISIL Inclusix matrix ranges from the national level to the regional level, state level, and district level.

World Bank calculates the Global Findex every three years by collecting the data on financial inclusion from 148 economies. Global Findex measures the penetration and usage level of payment services, savings, credit facilities, etc. and demonstrates how people around the world save, borrow, make payments, and manage risk. Many other comprehensive studies have been undertaken for measuring the progress of financial inclusion and comparing across economies (Sarma, 2016; Nanda \&Kaur, 2016). Allen et al. (2014) measure the level of financial inclusion and development in Africa and compare it with other developing countries.

\section{EXPLANATORY VARIABLES}

The literature on the factors that explain the level of financial inclusion can be widely classified on the basis of data used for research studies: (i) primary data-based studies; and (ii) secondary data-based studies. The primary data-based studies have attempted to explain the financial inclusion in terms of various socio-economic factors and financial factors such as gender, age, education, social class, caste, ethnicity, region, marital status, religion, household size, employment status, housing tenure, household income, sources for the economic and financial information, distance from the bank and the post office, awareness to the members of SHG, the topography of the area, presence or absence of a husband or adult man in the household, ownership of financial resources such as house and land, having loans receipt of government benefits, etc. (Bhanot et al., 2012; Devlin, 2009; Mukhopadhyay, 2016; Cnaan et al., 2012; Nandru et al., 2015; Demirguc-Kunt \& Klapper, 2012). CRISIL (2015) attributes the low level of financial inclusion into various causes such as lack of awareness, poverty, unemployment, illiteracy, distance from a bank branch, inconvenient branch timings, cumbersome documentation and procedures, unsuitable products, language barriers, staff attitudes, procedural hassles involved in formal banking services, easiness to borrow from informal credit sources, higher transactions costs involved, etc.

The secondary data-based studies have tried to find the correlation between financial inclusion and the explanatory variables such as GDP per capita, total population, rate of population growth, rate of unemployment, GDP growth rate, Rate of income tax, Fiscal Gini coefficient, rate of inflation, Ratio of NPA to Bank loan ratio, Government social expenditure rate, Population density, etc. (Beck, 2016; Kim, 2016). The ownership of the bank is found to have a significant moderating effect on the financial performance of banks (Aduda\&Kalunda, 2012). Various other researchers have attempted to relate the financial inclusion level with the ownership, and use of accounts and the deposit-credit penetration are related to per capita income level, the share of agriculture, increase in the bank branch network, factory proportion, employee base, literacy level, labour regulations, man-days lost, physical infrastructure, and institutional quality, etc. (Ghosh, 2012; Kumar, 2011). Morscher et al. (2017) finds the relationship with credit information sharing with the financial inclusion and account ownership at the financial institutions.

The financial inclusion of a country is associated with the macroeconomic factors such as stability of economic and political environments, documentation requirements to open an account and banking costs (Allen et al., 2012), population size, gender ratio, branch penetration, deposit to credit penetration ratio (Nandru et al., 2016), information \& communication techniques, awareness about financial services (Nandru et al., 2015; Demirguc-Kunt \& Klapper, 2013; Bhanot et al., 2012), remittances, income, inequality, urbanization, physical infrastructure for information sharing (Sarma\&Pai, 2011).

On the contrary, many other researchers have concentrated on discussing the leading influential factors that cause financial exclusion. The financial exclusion can be resulted out of various factors: non-availability, ineligibility, nonaffordability, financial illiteracy (Kim, 2016), absence of facilitating environment such as lower account costs, proximity to financial intermediaries, and the policies targeted to promote inclusion (Allen et al., 2012). The major challenges faced in extending formal financial services to the unbanked masses can be enumerated as financial illiteracy and the insufficient basic infrastructures such as telecommunications network and technological backwardness (Nanda \&Kaur, 2016); lower share of formal institutional credit, skewers in the accessibility to the formal credit between the developed regions and the less developed regions (Sachindra, 2013), non-accessibility into the banking other formal financial services, the high transaction cost of the formal accounts, excessive documentation procedures for opening ad operating the accounts, lack of connectivity with the rural regions, less collaboration among governmental departments, etc. Strategically framed befitting financial inclusion policies would lead to overcoming these barriers (Mundial, 2014). The assessment of the explanatory variables that influence the financial inclusion level will guide the policymakers to frame befitting financial inclusion policies.

\section{RESULTS AND DISCUSSIONS}

We have widely discussed the definitions of financial inclusion suggested by various researchers, and pointed out manifold benefits, numerous dimensions, and diverse explanatory variables of financial inclusion. At the initial phase of the concept' financial inclusion', the definitions were more stressed on the 'access' dimension alone. But at a later phase, 
the dimension of 'continued usage' was also introduced and emphasized along the access dimension. So, based on the analysis of various definitions accumulated from the literature, we can formulate a working definition on financial inclusion as Financial inclusion is the process of ensuring access and continued usage of formal financial services to all segments of the population, especially to the marginalized and the low-income households.

Among the various dimensions discussed in the literature, the most highlighted dimensions are 'accesses and 'usage', which deals with the supply side and the demand side information correspondingly. So, any attempts to assess the level of financial inclusion necessarily consider these two fundamental dimensions. In the several benefits enumerated, the most emphasized one is the financial stability achieved by the low-income segment through the Access and continued Usage of formal financial services. In its turn, the entry of the low-income households into the formal financial sector significantly contributes, at the macro level, to the growth of gross domestic product and the decline of shadow or informal economy in each country. The analysis of the explanatory variables reveals that the economic and demographic factors impact the level of financial inclusion. The in-depth studies on the behavioural, psychological, and social factors uncover why the financial inclusion level varies according to the demographic profile of the individuals.

\section{LIMITATION AND STUDY FORWARD}

The present study has several limitations. Firstly, this study has searched only direct keywords such as 'financial inclusion', and 'financial exclusion'; there are many synonymous terms used in the research literature as the keywords. Such papers may not have been captured in the search conducted in the present study. Secondly, since we have attempted to address the financial inclusion in a wider perspective, this study has covered numerous dimensions of financial inclusion such as definitions, impacts, measurements, explanatory variables, etc. Narrowing down the scope of the study into any single dimension would have resulted in an in-depth analysis of studies. (Future studies emphasizing more on the demand side variables of financial inclusion would explore to what extent the poor make use of the presently available banking and other formal financial services. The researches which employs the primary data is comparatively lesser in the area of financial inclusion; such studies would discover the attitude, behavioural reactions, and expectations of the poor towards the financial services provided by the banks and other financial institutions.

\section{CONCLUSION}

The primary objective of the paper was to make a detailed discussion on the recent trends in researches on financial inclusion. Through this review paper, we make certain observations. The concept of financial inclusion is more complex and deeper than popularly understood. Mere accessibility into the formal financial services need not necessarily be converted to the continued usage and contribute towards economic development and social welfare. However, opening a bank account is a very crucial step in the mission of financial inclusion. But this primary step is to be further supplemented by other financial services such as payment services, affordable formal credits, insurance, etc. The commercial banks and other formal financial institutions have succeeded, to a great extent, to create a profitable business model for the delivery of financial services to low-income households. Penetration, and accessibility, complimented by the strategies to improve the actual usage level, of the formal financial services would ensure economic prosperity and social well-being.

\section{AUTHORS CONTRIBUTION}

The first author has involved more in the identification of the topic, and the research problem, conceptualization of the study, and the writing of the first draft of the paper. The second author concentrated more on identifying relevant literature for reviewing, development of methodology, and improving the quality of the first draft of the paper.

\section{REFERENCES}

1. Aduda, J., \&Kalunda, E. (2012). Financial inclusion and financial sector stability with reference to Kenya: A review of literature. Journal of Applied Finance and Banking, 2(6), 95.

2. Aker, J., Boumnijel, R., McClelland, A., \& Tierney, N. (2013). How do electronic transfers compare? Evidence from a mobile money cash transfer experiment in Niger. Tufts University.

3. Aker, Jenny C., and Isaac M. Mbiti. 2010. "Mobile Phones and Economic Develop.https://doi.org/10.2139/ssrn.1693963

4. Allen, F., Carletti, E., Cull, R., Qian, J. Q., Senbet, L., \& Valenzuela, P. (2014). The African financial development and financial inclusion gaps. Journal of African economies, 23(5), 614-642. https://doi.org/10.1093/jae/eju015

5. Allen, F., Demirguc-Kunt, A., Klapper, L., \&Peria, M. S. M. (2012). The foundations of financial inclusion: Understanding ownership and use of formal accounts. Policy research working paper; No. WPS 6290. Washington, DC: World Bank Group. https://doi.org/10.1596/1813-9450-6290

6. Ambarkhane, D., Singh, A.S., \&Venkataramani, B. (2016).Measuring financial inclusion of Indian states.International Journal of Rural Management, 12(1), 72-100. https://doi.org/10.1177/0973005216633940

7. Anand, S., \&Chhikara, K. S. (2013). A theoretical and quantitative analysis of financial inclusion and economic growth, Management and Labour Studies,38(1-2), 103-133. https://doi.org/10.1177/0258042X13498009 
8. Aportela, F. (1999). Effects of financial Access on savings by low-income people.

9. Arora, R. U. (2010). Measuring financial access. Griffith Business School Discussion Papers Economics, (7).

10. Ashraf, N., Karlan, D., \& Yin, W. (2010). Female empowerment: Impact of a commitment savings product in the Philippines. World development, 38(3), 333-344. https://doi.org/10.1016/j.worlddev.2009.05.010

11. Bauchet, J., Marshall, C., Starita, L., Thomas, J., \&Yalouris, A. (2011). Latest findings from randomized evaluations of microfinance. In access to finance forum, 2. Washington, DC: World Bank, CGAP.https://doi.org/10.1596/26892

12. Beck, T. (2016). financial inclusion - measuring progress and progress in measuring. Fourth IMF statistical forum lifting the small boats: Statistics for inclusive growth. UK: Cass Business School, University of London.

13. Beck, T., Demirgüç-Kunt, A., \& Levine, R. (2007). Finance, inequality and the poor. Journal of economic growth, 12(1), 27-49.https://doi.org/10.1007/s10887-007-9010-6

14. Beck, T., Demirguc-Kunt, A., \& Martinez Peria, M. S. (2006). Banking services for everyone? Barriers to bank access and use around the world. Policy research working paper; No. WPS 4079, Washington, DC: World Bank.https://doi.org/10.1093/wber/lhn020

15. Beck, T., Demirguc-Kunt, A., and Martinez Peria, M.S. (2005). Reaching out: Access to and use of banking services across countries. Journal of Financial Economics, 85(1): 234-66. https://doi.org/10.1016/j.jfineco.2006.07.002

16. Bhanot, D., Bapat, V., \&Bera, S. (2012). Studying financial inclusion in north-east India. TheInternational Journal of Bank Marketing, 30(6): 465-484. https://doi.org/10.1108/02652321211262221

17. Bihari, S. (2011). Growth through financial inclusion in India. Journal of International Business Ethics, 4(1): 28-41.

18. Busch, M. O., Koetter, M., Krause, T., \&Tonzer, L. (2017). Broadening the G20 financial inclusion agenda to promote financial stability: The role for regional banking networks. G20 Insights, April, 4.

19. Camara, N., \&Tuesta, D. (2014). Measuring financial inclusion: A muldimensional index. BBVA Research Paper, (14/26).https://doi.org/10.2139/ssrn.2634616

20. Chibba, M. (2009). Financial inclusion, poverty reduction and the millennium development goals. The European Journal of Development Research, 21(2), 213-230. https://doi.org/10.1057/ejdr.2008.17

21. Cihak, M., Mare, D. S., \& Melecky, M. (2016). The nexus of financial inclusion and financial stability: A study of trade-offs and synergies. Policy research working paper; No. WPS 7722. Washington, D.C.: World Bank Group. https://doi.org/10.1596/1813-9450-7722

22. Cnaan, R. A., Moodithaya M. S., \& Handy F. (2012). Financial inclusion: lessons from rural South India. Journal of Social Policy, 41(1): 183-205. https://doi.org/10.1017/S0047279411000377

23. CRISIL (2015). CRISIL Inclusix: An Index to Measure India's Progress on Financial Inclusion, Vol. 3.

24. Cull, R., Ehrbeck, T., \&Holle, N. (2014). Financial inclusion and development: Recent impact evidence. Focus Note, 92, 1-12.

25. Demirguc-Kunt, A., \& Klapper L. (2012). Measuring financial inclusion: The global findex database. Policy research working paper; No. WPS 6025. Washington, DC: World Bank Group. https://doi.org/10.1596/18139450-6025

26. Demirguc-Kunt, A., \& Klapper, L. (2013). Measuring financial inclusion: Explaining variation in use of financial services across and within countries. Brookings Papers on Economic Activity, 2013(1), 279-340. https://doi.org/10.1353/eca.2013.0002

27. Demirguc-Kunt, A., Klapper, L., \& Singer, D. (2017). Financial inclusion and inclusive growth: A review of recent empirical evidence. Policy research working paper; No. 8040. Washington, DC: World Bank.https://doi.org/10.1596/1813-9450-8040

28. Devlin, J. F. (2009). An analysis of influences on total financial exclusion. The Service Industries Journal, 29(8), 1021-1036.

29. Dixit, R., \&Ghosh, M. (2013). Financial inclusion for inclusive growth of India-A study of Indian states. International Journal of Business Management \& Research, 3(1), 147-156.

30. Dupas, P., Green, S., Keats, A., \& Robinson, J. (2012). Challenges in banking the rural poor: Evidence from Kenya's western province (No. w17851). National Bureau of Economic Research. https://doi.org/10.3386/w17851

31. Farazi, S. (2014). Informal firms and financial inclusion: Status and determinants. Journal of international commerce, Economics and policy, 5(03). Policy research working paper; No. 6778. Washington, DC: World Bank. https://doi.org/10.1142/S1793993314400110

32. Ghosh, S. (2012). Determinants of banking outreach: An empirical assessment of Indian states. The Journal of Developing Areas, 46, 269-295. https://doi.org/10.1353/jda.2012.0034

33. Gupte, R., Venkataramani, B., \& Gupta, D. (2012). Computation of financial inclusion index for India. Procedia - Social and Behavioral Sciences, 37, 133-149. https://doi.org/10.1016/j.sbspro.2012.03.281

34. Hannig, A., \& Jansen, S. (2010). Financial inclusion and financial stability: Current policy issues. Working paper series; No. 259. Tokyo: Asian Development Bank Institute.https://doi.org/10.2139/ssrn.1729122 
35. Honohan, P. (2005). Measuring micro finance access: Building on existing cross-country data. Policy research working paper; no. WPS 3606. Washington, DC: World Bank. https://doi.org/10.1596/1813-9450-3606

36. Jain, A., \& Jain, A. (2013). Achieving financial inclusion under MGNREGA in a tribal hill district: A study of Chamba (HP). Journal of Land and Rural Studies, 1(2), 173-198. https://doi.org/10.1177/2321024913513382

37. Karpowicz, I. (2014). Financial inclusion, growth and inequality: a model application to Colombia. IMF Working Papers. 14. https://doi.org/10.5089/9781498344838.001

38. Kaur, H., \& Singh, K. N. (2015). PradhanMantri Jan Dhan Yojana (PMJDY): a leap towards financial inclusion in India. International Journal of Emerging Research in Management \&Technology, 4(1), 25-29.

39. Kendall, J., Ponce, A., \&Mylenko, N. (2010). Measuring financial access around the world, Policy research working paper; no. WPS 5253. Washington, DC: World Bank. https://doi.org/10.1596/1813-9450-5253

40. Kim, J. H. (2016). A study on the effect of financial inclusion on the relationship between income inequality and economic growth. Emerging Markets Finance and Trade, 52(2), 498-512. https://doi.org/10.1080/1540496X.2016.1110467

41. Kulkarni, M.M., \&Warke, P. (2015). The framework for assessment of ICT based financial inclusion management by nationalized banks with special reference to Marathwada region. Journal of Commerce \& Management Thought, 6(4): 684-692. https://doi.org/10.5958/0976-478X.2015.00041.5

42. Kumar, N. (2013). Financial inclusion and its determinants: evidence from India. Journal of Financial Economic Policy, 5(1), 4-19.https://doi.org/10.1108/17576381311317754

43. Ment in Africa." Journal of Economic Perspectives 24, no. 3:207-32.

44. Mohan, R. (2006). Economic growth, financial deepening and financial inclusion, RBI Bulletin, 1305-19.

45. Morgan, P., \&Pontines, V. (2014). Financial stability and financial inclusion. SSRN Electronic Journal. https://doi.org/10.2139/ssrn.2464018

46. Morscher, C., Horsch, A., \& Stephan, J. (2017). Credit information sharing and its link to financial inclusion and financial intermediation. Financial Markets, Institutions and Risks. $1.22-33$. https://doi.org/10.21272/fmir.1(3).22-33.2017

47. Mukhopadhyay, J. P. (2016). Financial Inclusion in India: A Demand-side Approach. Economic and Political Weekly, 51(49), 46-54.

48. Mundial, B. (2014). Global Financial Development Report 2014: Financial Inclusion. Washington, DC: World Bank.

49. Mylenko, C. (2009). Financial Access 2009: Measuring access to financial services around the world. The Consultative Group to Assist the Poor. Washington, DC: World Bank.

50. Nanda, K., \&Kaur, M. (2016). Financial inclusion and human development: a cross-country evidence. Management and Labour Studies, 41(2), 127-153. https://doi.org/10.1177/0258042X16658734

51. Nandru, P., Anand, B., \&Rentala, S. (2015). Financial inclusion in Pondicherry region: evidence from accessibility and usage of banking services. TSM Business Review, 3(2), 1-13.

52. Nandru, P., Byram, A., \&Rentala, S. (2016). Determinants of financial inclusion: Evidence from account ownership and use of banking services. International Journal of Entrepreneurship and Development Studies, 4(2), 141-155.

53. Rahman, Z. A. (2013). Developing a financial inclusion index. Central Bank. Retrieved from www. centralbanking. com/digital_assets/6715/CB23.4 May2013 Financial_inclusion_Rahman_New. pdf.

54. Rangarajan, C. (2008). Report of the committee on financial inclusion. Ministry of Finance, Government of India.

55. Sachindra, G. R. (2013). Need for financial inclusion and challenges ahead-an Indian perspective. IOSR Journal of Business and Management (IOSR-JBM), 9(5), 33-36.https://doi.org/10.9790/487X-0953336

56. Sarma, M. (2008). Index of financial inclusion. Indian Council for Research on International Economic Relations, New Delhi, India. Working paper No. 215.

57. Sarma, M. (2010). Index of financial inclusion (Discussion Paper No. 10-05). New Delhi, India: Centre for International Trade and Development (CITD), Jawaharlal Nehru University.

58. Sarma, M. (2012). Index of financial inclusion-A measure of financial sector inclusiveness. Centre for International Trade and Development, School of International Studies Working Paper Jawaharlal Nehru University. Delhi, India.

59. Sarma, M. (2016). Measuring financial inclusion using multidimensional data. World Economics, 17(1), 15-40.

60. Sarma, M., \&Pais, J. (2011). Financial inclusion and development. Journal of international development, 23(5), 613-628. https://doi.org/10.1002/jid.1698

61. Sethy, S. K. (2016). Developing a financial inclusion index and inclusive growth in India.Theoretical and Applied Economics, 23(2): 187-206. https://doi.org/10.1177/0019466220150210

62. Shah, P., \&Dubhashi, M. (2015). Review paper on financial inclusion-the means of inclusive growth. Chanakya International Journal of Business Research, 1(1), 37-48. https://doi.org/10.15410/cijbr/2015/v1i1/61403

63. Shehu, A. Y. (2012). Promoting financial inclusion for effective anti-money laundering and counter financing of terrorism (AML/CFT). Crime, law and social change, 57(3), 305-323. https://doi.org/10.1007/s10611-0119351-0 
Humanities \& Social Sciences Reviews

elSSN: 2395-6518, Vol 8, No 4, 2020, pp 192-200

https://doi.org/10.18510/hssr.2020.8420

64. Swamy, V. P. (2011). Financial inclusion in India: An evaluation of the coverage, progress, and trends. The IUP Journal of Financial Economics, 9(2), 7-26.

65. Tripathi, R., Yadav N., and Shastri R. (2016). Financial inclusion in India through PMJDY: an empirical analysis of statistical evidence. Indian Journal of Finance, 10(10): 42-53. https://doi.org/10.17010/ijf/2016/v10i10/103014

66. Yorulmaz, R. (2013). Construction of a regional financial inclusion index in Turkey. Journal of BRSA Banking and Financial Markets, 7(1): 79-101. 